\title{
Effectiveness of Native Vitamin D Therapy in Patients with Chronic Kidney Disease Stage 3 and Hypovitaminosis D in Colombia, South America
}

This article was published in the following Dove Press journal: International Journal of Nephrology and Renovascular Disease

\author{
Cesar A Restrepo-Valencia' \\ Jose $V$ Aguirre-Arango ${ }^{2}$ \\ Carlos G Musso ${ }^{3}$ \\ 'Professor Titular, Universidad de Caldas, \\ Manizales, Colombia; ${ }^{2}$ Professor \\ Catedratico, Universidad de Manizales, \\ Manizales, Colombia; ${ }^{3}$ Facultad de \\ Ciencias de la Salud, Universidad Simón \\ Bolívar, Barranquilla, Colombia
}

\begin{abstract}
Introduction: In a high percentage of patients with chronic kidney disease (CKD) low levels of vitamin D are detected. The purpose of this study was to evaluate if the native vitamin D therapy (cholecalciferol) in the patients with stage 3 and hypovitaminosis D allows to modify markers of bone and mineral metabolism once normal serum levels have been achieved.
\end{abstract}

Materials and methods: From an initial base of 297 patients with CKD and hypovitaminosis D, those with normal or high levels of PTH were chosen for therapy with native vitamin D. The initial administered dose was 1000 IU/day, with adjustments every 4 months of 1000 IU (maximum 4000 IU/day, according to RDA and IOM), until achieving serum levels of 25 hydroxyvitamin $\mathrm{D}$ greater than $30 \mathrm{ng} / \mathrm{mL}$ and lower than $80 \mathrm{ng} / \mathrm{mL}$. The variables calcium, phosphorus, intact parathormone (iPTH), creatinine and glomerular filtration rate (GFR) were also evaluated every 4 months.

Results: The total number of patients included in this study was 170 . Seventy-three patients were excluded along the follow-up: 17 non-responders (never achieved the projected serum levels of vitamin D), and 56 for not completing one year of follow-up. A total of 97 patients were finally included. In 82 patients, follow-up was achieved for 12 months (G1) and in 38 patients for 24 months (G2). In 15 patients despite achieving satisfactory levels of vitamin $\mathrm{D}$ at 12 months, it was not possible to obtain adequate levels of iPTH for their GFR according to K/DOQI 2003 guidelines and they were called refractory to therapy (G3). In both groups 1 and 2, a non-significant tendency to increase calcium and serum phosphorus was observed. iPTH decreased significantly at 12 and 24 months follow-up. In group 3, we opted at 12 months for conversion to calcitriol, with a significant reduction in iPTH values. In this group, the initial value of GFR was close to $30 \mathrm{~mL} / \mathrm{min}$, and its fall in time more significant than the other two groups to CKD stage 4 .

Conclusion: Cholecalciferol with adjustment in its dose, and obtaining normal serum levels is an excellent therapeutic alternative for the treatment of patients with CKD stage 3, and hypovitaminosis D. In the group of patients with GFR close to $30 \mathrm{~mL} / \mathrm{min}$, or lower values (stage 4), and with the presence of secondary hyperparathyroidism, the use of active form of vitamin D (calcitriol, paricalcitol) is recommended as the first therapeutic alternative.

Keywords: vitamin D, cholecalciferol, chronic kidney disease, hypovitaminosis D

\section{Introduction}

Active vitamin D (calcitriol) is necessary for the adequate intestinal absorption of calcium and phosphorus, calcium reabsorption in the distal convoluted tubule, and inhibition in the synthesis and secretion of the parathormone (PTH). The synthesis 
of the active vitamin $\mathrm{D}(1.25(\mathrm{OH}) 2 \mathrm{D}$ or calcitriol) requires the presence of adequate circulating blood levels of 25 hydroxyvitamin D3 or D2 (calcidiol (25(OH)D3) or ercalcidiol $(25(\mathrm{OH}) \mathrm{D} 2)$ ), which were filtrated in the glomeruli, reabsorbed by the cells in the proximal convoluted tubule and exposed to the mitochondrial enzyme 1 alfa hydroxylase. ${ }^{1}$ Various extrarenal cells in numerous tissues express 1 alfa hydroxylase, and possess the enzymatic capacity to convert 25 hydroxyvitamin D to calcitriol, where it may exert various local effects noncalcemic that include promotion of cell differentiation, induction of apoptosis, suppression of cell proliferation, and modulation of immune function. ${ }^{2,3}$

Recent KDIGO guidelines recommend that serum calcium, phosphorus, PTH, alkaline phosphatase and vitamin D $(25(\mathrm{OH}) \mathrm{D})$ levels be monitored in patients with chronic kidney disease (CKD) from stage 3, in order to practice early correction of the same, and avoid the appearance of bone and mineral disorders. ${ }^{4}$ The importance of such monitoring has been demonstrated by us in CKD patients of different stages, and in kidney transplant patients on whom we documented that vitamin D insufficiency and deficiency are common, findings that are more evident as kidney deterioration progresses. Its consequences are substrate deficit for the kidney, and impact on bone health which is reflected on the progressive increase of PTH levels and alkaline phosphatase with a decrease in serum calcium levels. ${ }^{5,6}$ In CKD patients and even in those patients on dialysis therapy, vitamin D serum levels have also been associated in various studies to a higher death rate due to overall causes, cardiovascular mobility, and a higher incidence of albuminuria, and its progression to higher stages. ${ }^{7-10}$

The aim of this study was to evaluate, in our previously reported population with stages $3 \mathrm{CKD}$, and kidney transplant patients, if oral administration of native vitamin D (cholecalciferol) in patients with low serum levels can raise their values to normal ranges, and modify markers of bone and mineral metabolism which could be present.

\section{Materials and Methods}

This study was carried out at the University of Caldas and RTS Caldas branch. The population studied lived in the city of Manizales, Caldas, Colombia, South America, where there are no significant seasonal variations throughout the year. The patients with stage $3 \mathrm{CKD}$ who took part in this study were taken from a previous database, in which those with levels deficit or insufficient of vitamin
D were identified. ${ }^{5,6}$ Exclusion criteria: having received native vitamin $\mathrm{D}$ in the last 6 months, having been treated with vitamin D selective or non-selective analogues or cinacalcet, suffering from liver failure, acute or chronic active infection, neoplasia, primary hyperparathyroidism, intestinal malabsorption disorders, and having serum levels of PTH lower than the lowest acceptable limit for glomerular filtration rate (GFR). In this sense, patients with intact PTH (iPTH) values lower than $30 \mathrm{pg} / \mathrm{mL}$ when the stage of CKD was 3 (GFR greater than $30 \mathrm{~mL} /$ minute/1.73 mt2) were excluded, due to their possibility of inducing adynamic bone, and according to international recommendations for when the study began. ${ }^{11,12}$ All the patients received an initial dose of $1000 \mathrm{IU} /$ day of vitamin D3 (cholecalciferol), and adjustments were made in 1000 IU every 4 months depending on the serum levels. The maximum projected dose was $4000 \mathrm{IU} /$ day, according to the maximum RDA (Recommended Dietary Allowance) and concept of IOM (Institute of Medicine) 2011. ${ }^{13}$ The goal was to obtain vitamin D serum levels between $30 \mathrm{ng} /$ $\mathrm{mL}$ and $80 \mathrm{ng} / \mathrm{mL}$ during the first 12 months of follow-up after administering vitamin $\mathrm{D}$, and then keep them in those rates for 24 months, adjusting the oral dose when necessary. ${ }^{9} \quad$ The above-mentioned serum vitamin D values were chosen since values higher than $80 \mathrm{ng} / \mathrm{mL}$ have been considered compatible with high levels, thus avoiding reaching vitamin D toxicity levels: higher than $120 \mathrm{ng} / \mathrm{mL} .{ }^{14-16}$ In the patients who developed hypercalcemia or vitamin D levels higher than $80 \mathrm{ng} / \mathrm{mL}$ vitamin D dose was either reduced in $1000 \mathrm{IU} /$ day or suspended depending on the physician criterion. Hyperphosphatemia was initially prevented by nutritional recommendations, and in those who presented it, in addition to intensifying the diet was used for all groups calcium carbonate or a short period of aluminum hydroxide as an oral phosphate binder. ${ }^{17}$ The foregoing, given that by the date we conducted the study we did not have other binders such as sevelamer carbonate. After applying the previous protocol we found 3 groups of patients, which we decided to call as follows: the first group as "non-responders": patients in whom after 12 months of treatment, and having received the maximum projected dose of $4000 \mathrm{IU} /$ day failed to achieve serum vitamin D levels greater than $30 \mathrm{ng} / \mathrm{mL}$. The second group as "responders": characterized by achieving satisfactory vitamin D serum levels, and the third group as "refractories": patients who were refractories to therapy with native vitamin $\mathrm{D}$, those patients in which despite obtaining serum vitamin D levels greater 
than or equal to $30 \mathrm{ng} / \mathrm{mL}$, exhibited persistent elevation in iPTH levels to values greater than $70 \mathrm{pg} / \mathrm{mL}$ when their GFR was greater than $30 \mathrm{~mL} / \mathrm{min}$, or iPTH greater than $110 \mathrm{pg} / \mathrm{mL}$ with GFR between 15 and $30 \mathrm{~mL} / \mathrm{min} .{ }^{11}$ In this last group of patients, cholecalciferol was discontinued and calcitriol was prescribed at an initial dose of 0.25 ug, with increases of 0.25 ug every 4 months depending on the response, due to its demonstrated ability to affect iPTH in this group of patients, in whom its long-term use has been questioned. ${ }^{18,19}$

The patients were monitored for serum vitamin D levels (by electrochemiluminescence), calcium, phosphorus, creatinine and iPTH every 4 months. The GFR was calculated by the 4 variables MDRD equation, with the standardized serum creatinine assay. ${ }^{20}$ The levels of alkaline phosphatase or bone mineral density were not routinely evaluated. The levels of $25(\mathrm{OH}) \mathrm{D}$ were defined according to the relationship among the vitamin D serum levels, parathormone and intestinal transport of calcium according to the International Osteoporosis Foundation and National Osteoporosis Foundation 2005-2010, ${ }^{21,22}$ American Geriatrics Society Consensus ${ }^{23}$ and observations regarding the prevalence of the detected levels in the Middle East, and some regions of Europe and Asia. ${ }^{24-26}$ Values higher than $30 \mathrm{ng} / \mathrm{mL}$ ( $75 \mathrm{nmol} / \mathrm{L})$ were considered normal, insufficient between 11 and $30 \mathrm{ng} / \mathrm{mL}$ (25 a 75 $\mathrm{nmol} / \mathrm{L})$, and deficient lower than $10 \mathrm{ng} / \mathrm{mL}$ (25 nmol/L). The value recommended by The Endocrine Society (USA) was not taken into consideration since for our initial studies $^{5,6}$ it was probable that the number of patients detected in deficit (values lower than $20 \mathrm{ng} / \mathrm{mL}$ ) was very high, which could impact highly on the selected therapy. $^{27}$ Three groups were identified for the report: Group 1 (G1): patients who completed 1 year (48 weeks) of follow-up, Group 2 (G2): patients who completed 2 years of follow-up (96 weeks). Group 3 (G3): patients refractory to therapy with vitamin $\mathrm{D}$ and converted to calcitriol. SPSS statistical package version 20 was used to determine the statistically significant differences in all the groups and in each of the laboratory tests during the follow-up. To conclude the existence of lack of it among the tests, the method chosen was the distribution of the probability $\mathrm{t}$ of student for samples related and the value $\mathrm{p}<0.05$ allowed us to identify the presence of such differences. Neither consent form nor authorization from the patients was required since the therapy supplied did not constitute an experimental test and is recommended by international guidelines. The study was a original research, and approved by the research committee of RTS for Colombia, and Bioethics of the University of Caldas.

\section{Results}

Our initial base was 297 patients, 268 with insufficient vitamin D levels and 29 in deficit; 127 patients at admission were excluded by several factors: 46 patients had PTH levels below those accepted for their GFR, 23 were in stage 5, 3 with CKD stage 4 were re-transplanted, and 55 had been transferred to another renal unit. ${ }^{5,6}$ The total number of patients included in this study was 170 . Seventy-three patients were excluded along the follow-up: 17 non-responders and 56 for not completing one year of follow-up or for not completing the number of additional studies required every 4 months. The latter due to factors connected with the health contracting system operating in Colombia, with frequent transfers to other health facilities, with which it was impossible to establish a satisfactory relationship to determine the evolution of the patients. Ninety-seven (97) patients were finally included in the data base for statistical analysis, 82 patients from Groups 1 and 2 and 15 from Group 3. Eighty-two patients formed the G1 and finished the 48-week follow-up. Their initial vitamin

Table I Vitamin D Levels in Each Group

\begin{tabular}{|c|c|c|c|c|c|c|c|c|}
\hline \multirow[t]{2}{*}{ Marker } & \multirow[t]{2}{*}{ Groups } & \multicolumn{7}{|c|}{ Measurement Time } \\
\hline & & Basal Initial & 4 Months & 8 Months & 12 Months & 16 Months & 20 Months & 24 Months \\
\hline Average & 1 & 17.9 & 30.0 & 35.5 & 36.3 & - & - & - \\
\hline Standard deviation & & 5.6 & 9.3 & 11.5 & 4.7 & - & - & - \\
\hline Average & 2 & 17.5 & 30.9 & 35.5 & 35.5 & 35.8 & 37.1 & 37.4 \\
\hline Standard deviation & & 5.0 & 11.6 & 11.6 & 8.6 & 7.7 & 4.4 & 6.6 \\
\hline Average & 3 & 16.2 & 22.0 & 26.7 & 38.8 & - & - & - \\
\hline Standard deviation & & 6.1 & 5.5 & 6.5 & 8.1 & - & - & - \\
\hline
\end{tabular}




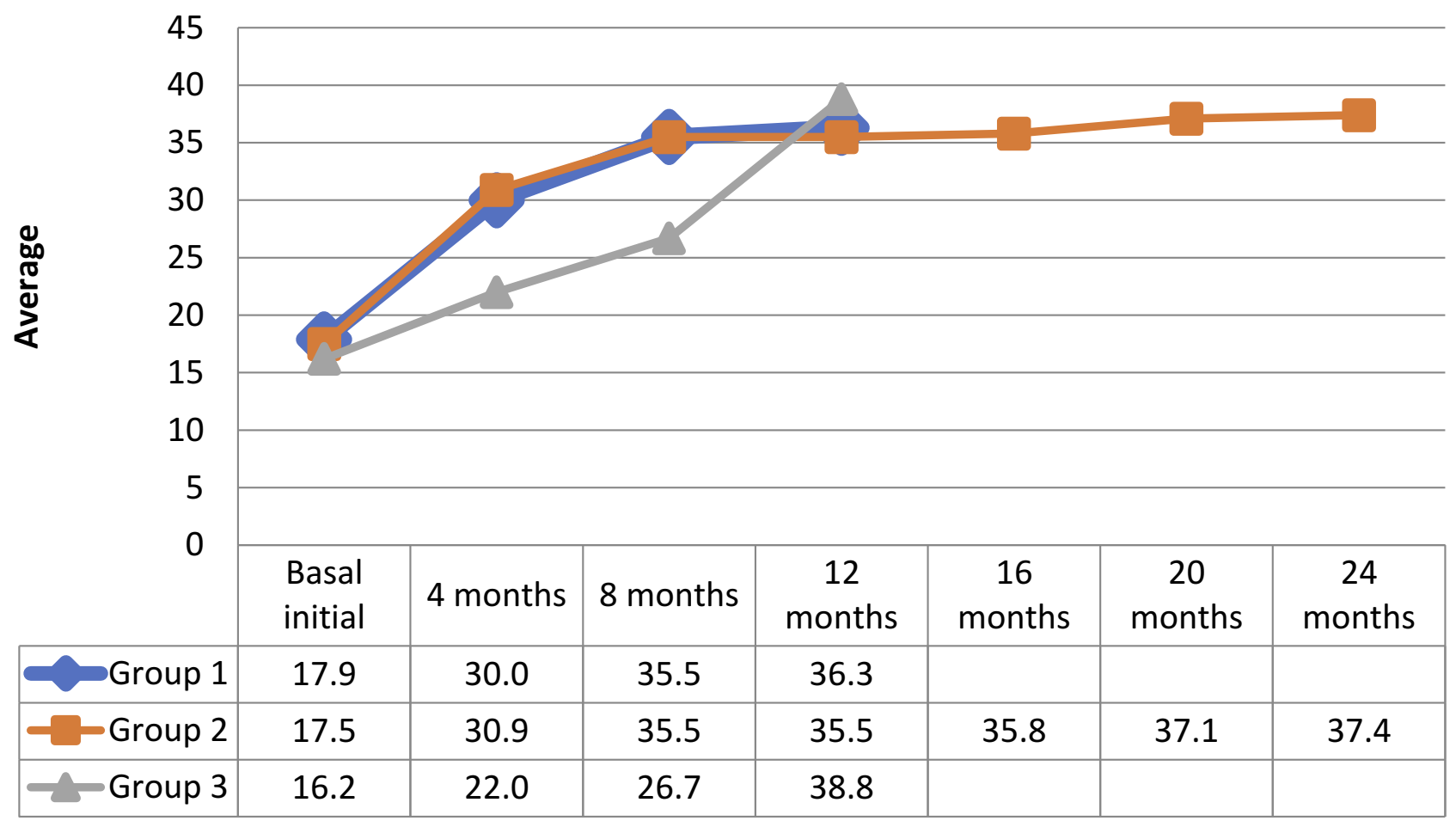

Figure I Average results of vitamin D levels in each group.

D levels were $17.9 \pm 5.6 \mathrm{ng} / \mathrm{mL}$, and 12 months later were 36.3 $\pm 4.7 \mathrm{ng} / \mathrm{mL}$ (Table 1, Figure 1). In this group, the change in the initial value of the variables and 12 months later for serum calcium was from $9.3 \pm 0.5 \mathrm{mg} / \mathrm{dL}$ to $9.5 \pm 0.8 \mathrm{mg} / \mathrm{dL}$, for serum phosphorus from $3.7 \pm 0.7 \mathrm{mg} / \mathrm{dL}$ to $3.8 \pm 0.7 \mathrm{mg} / \mathrm{dL}$, for iPTH from $97.5 \pm 50.7 \mathrm{pg} / \mathrm{mL}$ to $65.6 \pm 31.0 \mathrm{pg} / \mathrm{mL}$. In addition, the glomerular filtration rate (GFR) changed from $34.24 \pm 13.84 \mathrm{~mL} / \mathrm{min} / 1.73 \mathrm{~m}^{2}$ to $31.41 \pm 14.15 \mathrm{~mL} / \mathrm{min} /$ $1.73 \mathrm{~m}^{2}$ (GFR decline $2.83 \mathrm{~mL} / \mathrm{min} / 1.73 \mathrm{~m}^{2} /$ year). In general, it was observed that the levels of serum calcium and phosphorus increased slightly, whereas iPTH and GFR values decreased. A statistically significant difference was documented in serum calcium, GFR and iPTH values (Table 2, Figure 2). In the G2, 38 patients were followed for 96 weeks. Initially, their vitamin D levels were $17.5 \pm$ $5.0 \mathrm{ng} / \mathrm{mL}$, and later they were modified to $35.5 \pm 8.6 \mathrm{ng} / \mathrm{mL}$ after 12 months, and $37.4 \pm 6.6 \mathrm{ng} / \mathrm{mL}$ after 24 months (Table 1 and Figure 1). No significant changes were observed at 12 or 24 months in serum calcium or phosphorus levels. GFR value changed from an initial value of $35.9 \pm 14.7 \mathrm{~mL} /$ $\min / 1.73 \mathrm{~m}^{2}$ to $32.1 \pm 15.3 \mathrm{~mL} / \mathrm{min} / 1.73 \mathrm{~m}^{2}$ at 24 months (GFR decline $1.88 \mathrm{~mL} / \mathrm{min} / 1.73 \mathrm{~m}^{2} /$ year), and iPTH from $105.1 \pm 50.6 \mathrm{pg} / \mathrm{mL}$ to $66.2 \pm 20.5 \mathrm{pg} / \mathrm{mL}$. A statistically significant difference was documented in GFR and iPTH levels in this group (Table 3, Figure 3). The required average dose to obtain adequate vitamin D levels in the 82 patients was $1600 \pm 690 \mathrm{IU} /$ day, $28(34.15 \%)$ patients needed a dose of $1000 \mathrm{IU}, 48(58.54 \%)$ of $2000 \mathrm{IU}$, and $6(7.32 \%)$ of $4000 \mathrm{IU}$. Fifteen patients were refractory to vitamin D therapy (G3). In all the cases, with the progressive adjustment of the dose, it was possible to achieve levels higher than $30 \mathrm{ng} / \mathrm{mL}$ at

Table 2 Main Variables Characteristics \& Statistic Test, Group I

\begin{tabular}{|c|c|c|c|c|}
\hline \multirow[t]{2}{*}{ Laboratories } & \multicolumn{4}{|l|}{ Group I } \\
\hline & $\begin{array}{l}\text { GFR } \\
(\mathrm{mL} / \mathrm{min} / \\
\left.1.73 \mathrm{~m}^{2}\right)\end{array}$ & $\begin{array}{l}\text { Calcium } \\
\text { (mg/dl) }\end{array}$ & $\begin{array}{l}\text { Phosphorus } \\
\text { (mg/dl) }\end{array}$ & $\begin{array}{l}\text { iPTH } \\
(\mathrm{pg} / \mathrm{mL})\end{array}$ \\
\hline Average initial & 34.2 & 9.3 & 3.7 & 97.5 \\
\hline S.D. initial & 13.8 & 0.5 & 0.7 & 50.7 \\
\hline Average 4 months & 32.9 & 9.4 & 3.8 & 74.7 \\
\hline S.D. 4 months & 14.2 & 0.6 & 0.7 & 40.6 \\
\hline Average 8 months & 32.8 & 9.5 & 3.9 & 75.2 \\
\hline S.D. 8 months & 13.6 & 0.7 & 0.7 & 36.1 \\
\hline Average 12 months & 31.4 & 9.5 & 3.8 & 65.6 \\
\hline S.D. 12 months & 14.1 & 0.8 & 0.7 & 31.0 \\
\hline$t$ Test & 3.18 & -1.77 & -0.92 & 4.88 \\
\hline $\mathrm{p}$ Value & 0.02 & 0.08 & 0.36 & 0.00 \\
\hline
\end{tabular}

Abbreviations: GFR, glomerular filtration rate; S.D, standard deviation; iPTH, intact parathyroid hormone. 


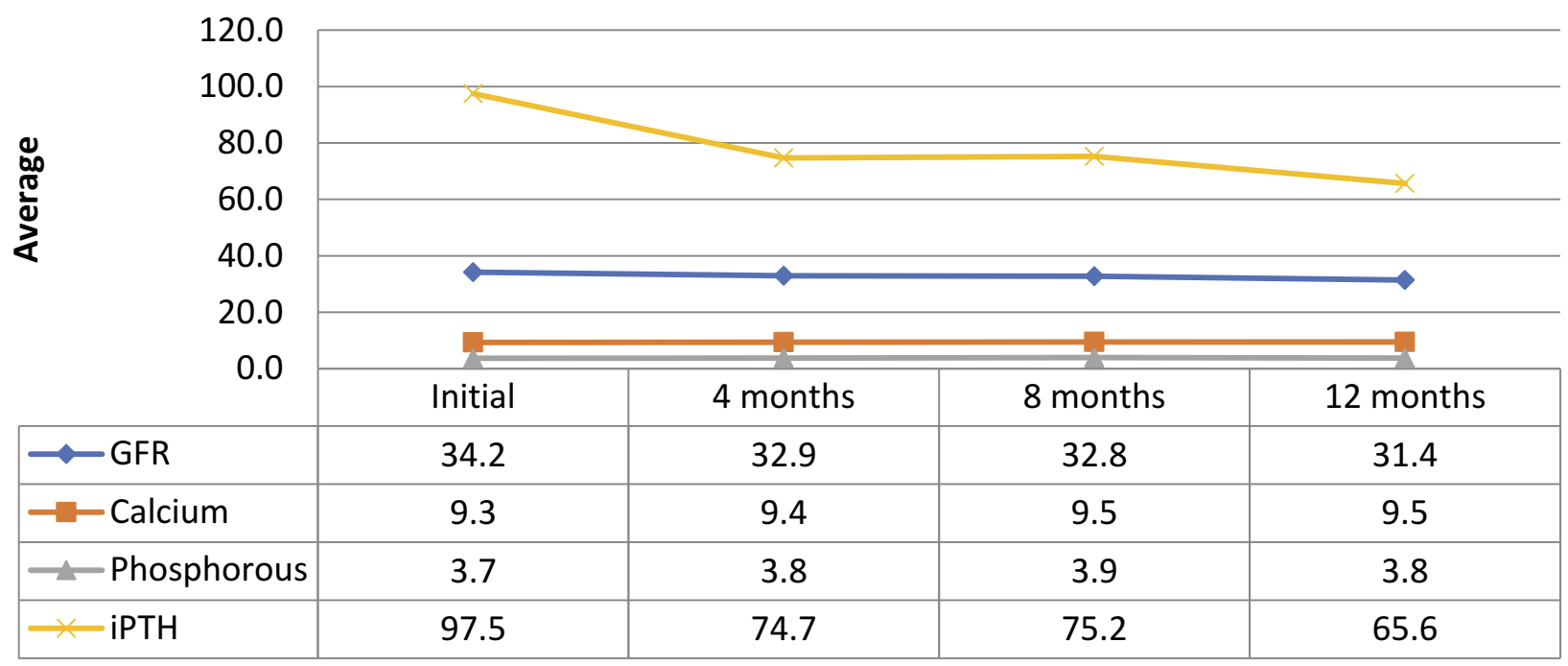

Figure 2 Average results of group I laboratories, since beginning to 12 months. Abbreviations: GFR, glomerular filtration rate; iPTH, intact parathyroid hormone.

12 months. The initial values of vitamin D were $16.2 \pm 6.1 \mathrm{ng} /$ $\mathrm{mL}$, and those before opting for conversion to calcitriol $38.8 \pm$ $8.1 \mathrm{ng} / \mathrm{mL}$ (Table 1, Figure 1), requiring a final vitamin D dose of $1630 \pm 488 \mathrm{IU}$. Regarding the GFR in this group, its initial value was $33.1 \pm 10.9 \mathrm{~mL} / \mathrm{min} / 1.73 \mathrm{~m}^{2}$, and at the moment of

Table 3 Main Variables Characteristics \& Statistic Test, Group 2

\begin{tabular}{|c|c|c|c|c|}
\hline \multirow[t]{2}{*}{ Laboratories } & \multicolumn{4}{|l|}{ Group 2} \\
\hline & $\begin{array}{l}\text { GFR } \\
(\mathrm{mL} / \mathrm{min} / \\
\left.1.73 \mathrm{~m}^{2}\right)\end{array}$ & $\begin{array}{l}\text { Calcium } \\
(\mathrm{mg} / \mathrm{dl})\end{array}$ & $\begin{array}{l}\text { Phosphorus } \\
\text { (mg/dl) }\end{array}$ & iPTH \\
\hline Average initial & 35.9 & 9.3 & 3.8 & 105.1 \\
\hline S.D. initial & 14.7 & 0.4 & 0.7 & 50.6 \\
\hline Average 4 months & 34.6 & 9.4 & 3.6 & 80.6 \\
\hline S.D. 4 months & 13.5 & 0.5 & 0.7 & 37.1 \\
\hline Average 8 months & 34.3 & 9.5 & 3.8 & 75.6 \\
\hline S.D. 8 months & 13.8 & 0.8 & 0.6 & 34.0 \\
\hline Average 12 months & 34.0 & 9.4 & 3.7 & 70.6 \\
\hline S.D. 12 months & 14.6 & 0.9 & 0.6 & 31.2 \\
\hline Average 16 months & 33.3 & 9.4 & 3.8 & 79.7 \\
\hline S.D. 16 months & 13.6 & 0.7 & 0.7 & 33.7 \\
\hline Average 20 months & 32.3 & 9.4 & 3.8 & 63.2 \\
\hline S.D. 20 months & 13.3 & 0.8 & 0.6 & 23.0 \\
\hline Average 24 months & 32.1 & 9.4 & 4.0 & 66.2 \\
\hline S.D. 24 months & 15.3 & 0.5 & 0.5 & 20.5 \\
\hline$t$ Test & 5.19 & 0.33 & -1.02 & 5.12 \\
\hline $\mathrm{p}$ Value & 0.00 & 0.74 & 0.31 & 0.00 \\
\hline
\end{tabular}

Abbreviations: GFR, glomerular filtration rate; S.D, standard deviation; iPTH, intact parathyroid hormone. conversion, it was $27.8 \pm 10.1 \mathrm{~mL} / \mathrm{min} / 1.73 \mathrm{~m}^{2}$ (GFR decline $5.36 \mathrm{~mL} / \mathrm{min} / 1.73 \mathrm{~m}^{2} /$ year). After the changing to calcitriol, the patients were followed for 8 more months, requiring an average dose of $0.258 \pm 0.046 \mathrm{ug}$. The evolution of the serum calcium, phosphorus, iPTH variables, before and after converting to calcitriol can be observed in Table 4 and Figure 4. In general, serum calcium and phosphorus tended to increase. iPTH had an initial value of $134.9 \pm 58.2 \mathrm{pg} / \mathrm{mL}$, and 12 months after therapy with vitamin D its value was $125.9 \pm$ $49.2 \mathrm{pg} / \mathrm{mL}$. After the conversion to calcitriol, these values changed to $93.7 \pm 30.3 \mathrm{pg} / \mathrm{mL}, 82.0 \pm 16.3 \mathrm{pg} / \mathrm{mL}$ at month 16 and 20 of incorporation into the study, respectively (Table 4, Figure 4). A statistically significant difference was documented in the changes presented by the GFR and iPTH variables. During the treatment, hypercalcemia was observed in only three patients, who responded well to the dose adjustment of cholecalciferol, although it was common for hypercalcemia to extend for up to three months, reflecting the average prolonged life of cholecalciferol.

\section{Discussion}

Active vitamin D synthesis $(1.25(\mathrm{OH}) 2 \mathrm{D})$ is a process that starts in the skin with exposure of 7-dehydrocholesterol to ultraviolet light generating pre-vitamin D3, which later experiences thermal isomerization, later converted to vitamin D3 in the liver due to the action of enzyme 25 hydroxylase which generates 25 hydroxyvitamin D3 (calcidiol (25(OH)D3)), which is filtrated in the glomeruli, reabsorbed by the proximal convoluted tubule cells and exposed to the mitochondrial enzyme CYP27B1 (1 alfa hydroxylase), generating the active 


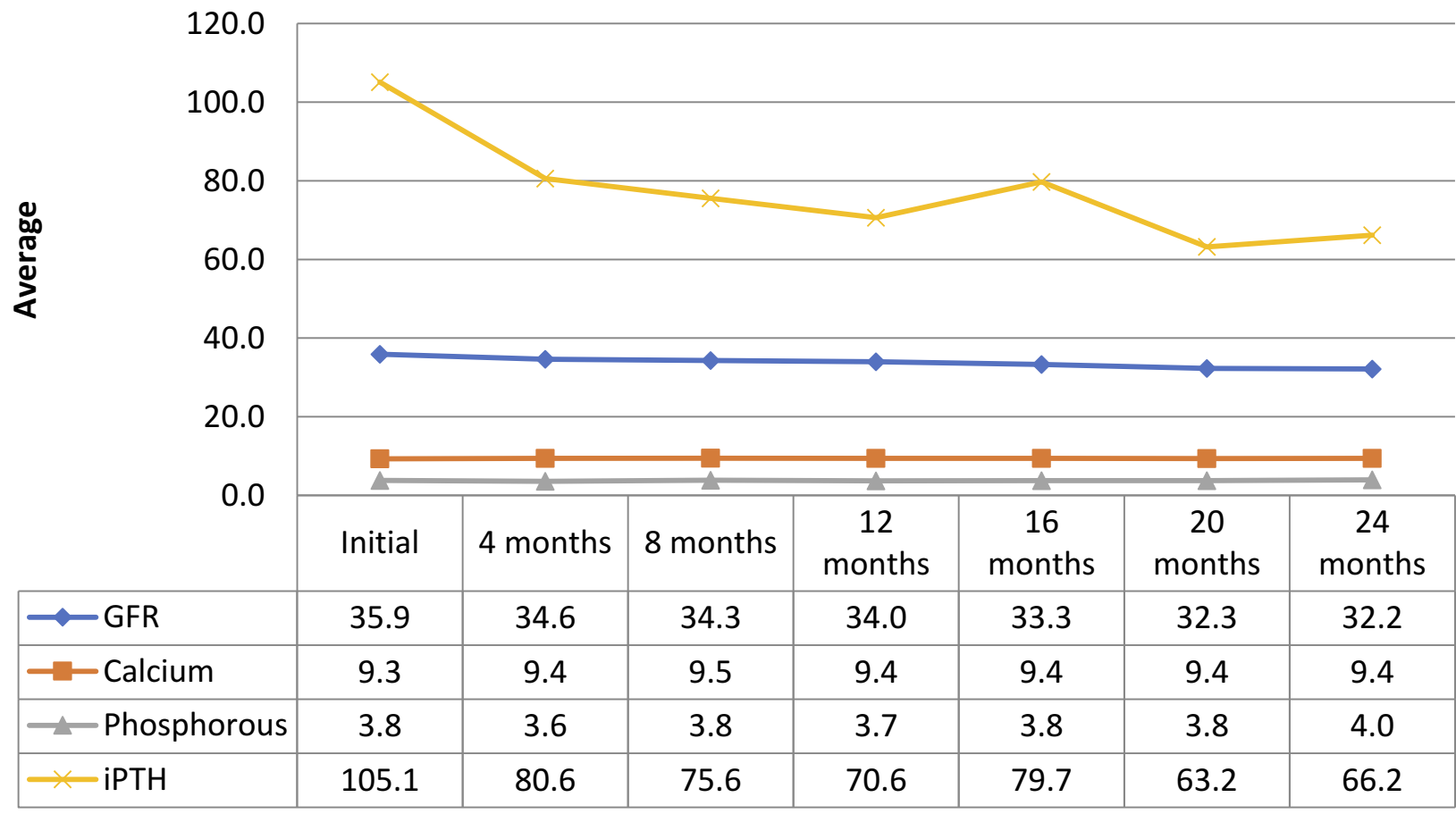

Figure 3 Average results of group 2 laboratories, since beginning to 24 months. Abbreviations: GFR, glomerular filtration rate; iPTH, intact parathyroid hormone.

form. ${ }^{1}$ Typically, the concept of adequate serum levels of vitamin D has been supported by its ability to avoid the increase of PTH levels above its normal values, which is

Table 4 Main Variables Characteristics \& Statistic Test, Group 3

\begin{tabular}{|c|c|c|c|c|}
\hline \multirow[t]{2}{*}{ Laboratories } & \multicolumn{4}{|l|}{ Group 3} \\
\hline & $\begin{array}{l}\text { GFR } \\
(\mathrm{mL} / \mathrm{min} / \\
\left.1.73 \mathrm{~m}^{2}\right)\end{array}$ & $\begin{array}{l}\text { Calcium } \\
\text { (mg/dl) }\end{array}$ & $\begin{array}{l}\text { Phosphorus } \\
\text { (mg/dl) }\end{array}$ & iPTH \\
\hline Average initial & 33.1 & 9.3 & 4.0 & 134.0 \\
\hline S.D. initial & 10.9 & 0.5 & 0.6 & 58.2 \\
\hline Average 4 months & 30.7 & 9.5 & 4.2 & 123.1 \\
\hline S.D. 4 months & 10.6 & 0.6 & 0.7 & 54.4 \\
\hline Average 8 months & 29.1 & 9.2 & 4.2 & 127.9 \\
\hline S.D. 8 months & 11.3 & 0.5 & 0.7 & 55.0 \\
\hline Average 12 months & 27.8 & 9.3 & 3.9 & 125.9 \\
\hline S.D. 12 months & 10.1 & 0.7 & 0.5 & 49.2 \\
\hline Average 16 months & 28.7 & 9.4 & 4.0 & 93.7 \\
\hline S.D. 16 months & 11.6 & 0.6 & 0.6 & 30.3 \\
\hline Average 20 months & 26.5 & 9.5 & 4.1 & 82.0 \\
\hline S.D. 20 months & 10.5 & 0.6 & 0.5 & 16.3 \\
\hline$t$ Test & 2.19 & -0.30 & -0.93 & 4.05 \\
\hline$p$ Value & 0.05 & 0.77 & 0.37 & 0.00 \\
\hline
\end{tabular}

Abbreviations: GFR, glomerular filtration rate; S.D, standard deviation; iPTH, intact parathyroid hormone. achieved with values higher than $31 \mathrm{ng} / \mathrm{mL}(78 \mathrm{nmol} / \mathrm{L}){ }^{28}$ but when analyzing the values per age in young adults it would be $28 \mathrm{ng} / \mathrm{mL}(70 \mathrm{nmol} / \mathrm{L})$, and in people older than 75 would be $40 \mathrm{ng} / \mathrm{mL}(100 \mathrm{nmol} / \mathrm{L}),{ }^{29}$ although in another study the concentrations of PTH were elevated with base serum levels of calcidiol lower than $44 \mathrm{ng} / \mathrm{mL}(110 \mathrm{nmol} / \mathrm{L}){ }^{30}$ The Medical Institute (IOM) suggests that vitamin D levels close to $20 \mathrm{ng} /$ $\mathrm{mL}(50 \mathrm{mmol} / \mathrm{L})$ fulfill the requirements of $97.5 \%$ of the global population, but in its conclusions it establishes the limit of 30 $\mathrm{ng} / \mathrm{mL}(75 \mathrm{nmol} / \mathrm{L})$ as the limit value above which there is not enough evidence to obtain more benefits in bone health. ${ }^{31}$ In favor of $30 \mathrm{ng} / \mathrm{mL}$ level are the results of the post-mortem bone histological analysis of iliac crests in individuals without secondary bone disease, in whom a defective bone mineralization was documented when the serum levels of vitamin D taken also during the autopsy were identified under $30 \mathrm{ng} / \mathrm{mL}$ (75 $\mathrm{mmol} / \mathrm{L}){ }^{32}$ There is agreement in the recent KDIGO and European Pediatric Nephrology guidelines for bone and mineral disorders in CKD (the latter applicable to patients under 18 years of age) that it is advisable to determine serum vitamin $\mathrm{D}$ levels in patients with $\mathrm{CKD}$, recognizing that such levels are marker of bone status, although they reflect is sun exposure. ${ }^{4,33}$ They also recommended that in stages 3 to $5 \mathrm{D}$ CKD patients who have been detected with insufficient levels or deficit of vitamin D should be corrected to prevent the onset of hyperparathyroidism, or correct it if it would be present. 


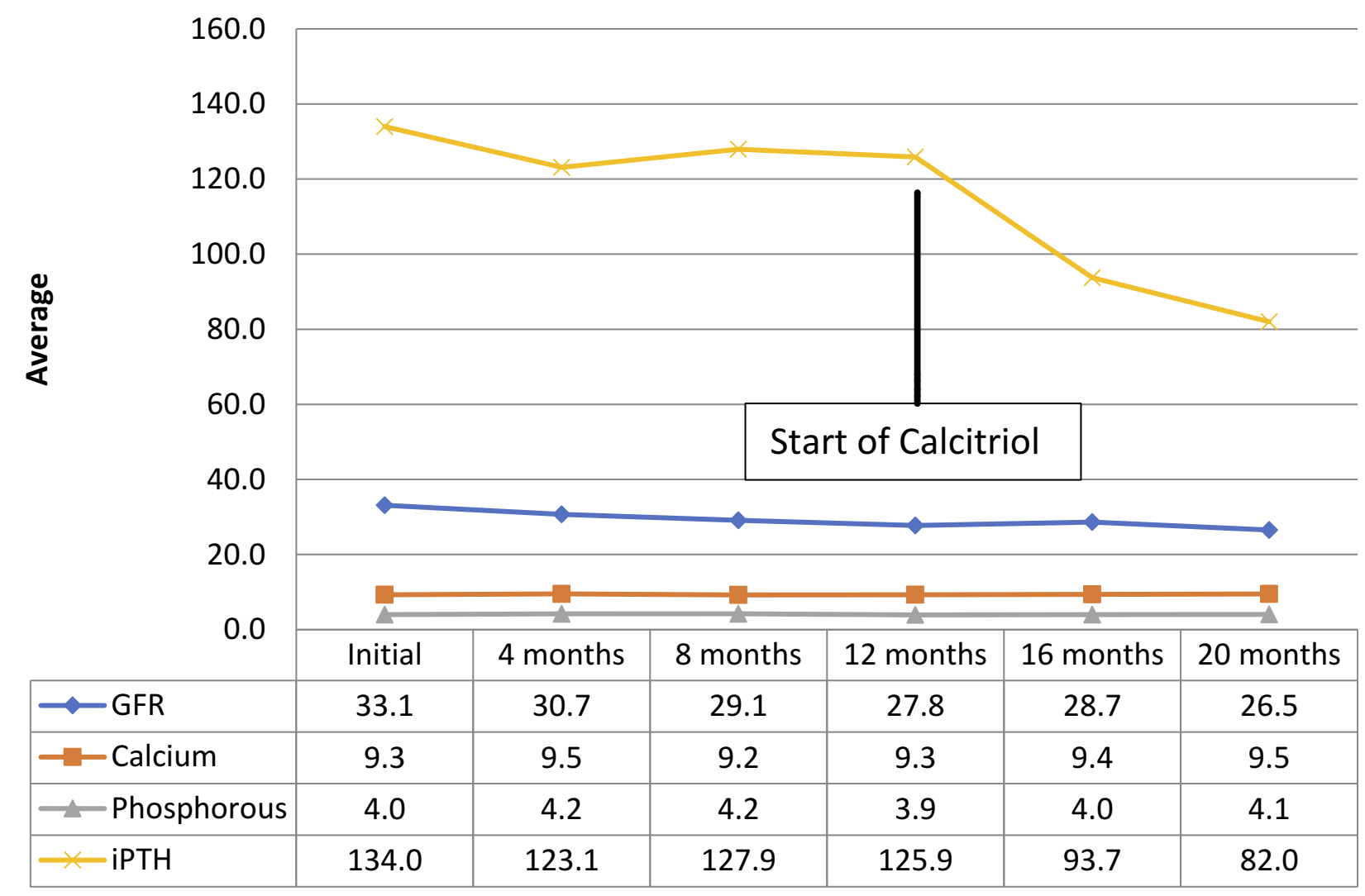

Figure 4 Average results of group 3 laboratories, since beginning to 20 months.

Abbreviations: GFR, glomerular filtration rate; iPTH, intact parathyroid hormone.

There are few studies with preventive intervention. In one of them carried out in 40 children with stage 2 to $4 \mathrm{CKD}$ who were detected low levels of vitamin $\mathrm{D}$, the administration of the supplement ergocalciferol for 12 months significantly reduced the appearance of secondary hyperparathyroidism compared with the placebo, applicable recommendation mainly in patients with stages 2 and 3, since it was observed that in patients with stage 4 ergocalciferol therapy failed to increase serum levels to normal values. ${ }^{34}$ The European Guidelines for Pediatric Nephrology admit that there are few prospective studies which inform the results of the treatment with native vitamin $\mathrm{D}$ in $\mathrm{CKD}$ children with stages 2 to $5 \mathrm{D}$ and end up giving recommendations based on systemic revisions of controlled clinical trials. ${ }^{33}$ In CKD patients who were diagnosed with vitamin D deficit, increasing exposure to the sun becomes an excellent alternative. In this group of patients, it has been observed that solar exposure or total body ultraviolet B radiation (UBV) increases serum levels from 25(OH) D3 in a $400 \%$, compared with the $60 \%$ achieved by $35,000 \mathrm{IU}$ of vitamin D3 per week. However, it is worth pointing out that it is difficult to maintain a sustained adherence to solar therapy, which can also cause skin injuries which may be important in a specific group of patients. ${ }^{35}$ There is no clear consensus regarding the type of vitamin D that should be prescribed, dose, frequency of administration and duration of the treatment in patients who exhibit low serum levels. The KDOQI guidelines recommend different dose, depending on the base value of 25-hydroxyvitamin D, starting the scheme with an initial loading dose or a period of intensive replacement for 4 to 6 weeks followed by a maintenance regimen. ${ }^{36}$ In recent revision which includes the studies in adult people from 2008 until 2016, very variable results were observed in the ability of native vitamin D to impact favorably PTH serum levels. In the study group which used cholecalciferol, there were works in which interval therapy was used in periods as short as 4 weeks. ${ }^{37}$ In others, the number of patients intervened was very small (20 patients), and in others, the goal of achieving serum cholecalciferol levels equal to or greater than $30 \mathrm{ng} / \mathrm{mL}$ was not achieved ( $30 \%$ of the studies). Only in a study that extended for 52 weeks in which 46 patients with CKD stages 2 and 3 were included, was it possible to obtain serum levels of 25-hydroxyvitamin D greater than $30 \mathrm{ng} / \mathrm{mL}$, with good short-term results (12 weeks), but without major long-term changes. ${ }^{38}$ 
In a more recent study it was observed that high doses of cholecalciferol (8000 IU per day), and for a period of 12 weeks achieved in patients with stage 3 and 4 CKD and secondary hyperparathyroidism adequate serum levels of 25hydroxyvitamin D (162 $\pm-49 \mathrm{nmol} / \mathrm{L})$, and they prevented its progression by stabilizing the $\mathrm{PTH} .{ }^{39}$ In another study, cholecalciferol supplementation was evaluated in non-diabetic patients deficient in vitamin $\mathrm{D}$, with CKD stage 3 and $4 \mathrm{CKD}$. The patients received two doses of 300.000 IU with a difference of 8 weeks vs placebo. Sixteen weeks after the first dose, elevated levels of 25-hydroxyvitamin D, 1.25-hydroxyvitamin D and serum calcium was observed, together with the decrease in the total values of serum alkaline phosphatase, bone-specific, and type I C-telopeptide, unlike the placebo. ${ }^{40}$ The prescription of ergocalciferol has also been analyzed. A revision which included 7 observations pointed out that $85 \%$ of the cases achieved satisfactory levels of 25-hydroxyvitamin $\mathrm{D}$, but that in $71 \%$ of the cases there was not a good therapeutic response. ${ }^{37}$ In one study, ergocalciferol administered for 6 months raised serum levels of 25-hydroxyvitamin D to $27.2 \mathrm{ng} / \mathrm{mL}$, and reduced PTH by $20-25 \%$ in patients with stage $3 \mathrm{CKD}$, but was ineffective in stage $4 .{ }^{41}$ Similar findings were described in another study in which CKD patients with stage 3 and 4 who suffered from hyperparathyroidism and hypovitaminosis $\mathrm{D}$ in whom ergocalciferol was used in adjusted quarterly dose for 6 to 7 months. It was observed that the average levels of vitamin D normalized in both groups, but PTH values decreased only in the group with stage $3 \mathrm{CKD}$ patients. ${ }^{42}$ Nevertheless, a high dose of Ergocalciferol, which result in vitamin D levels greater than $30 \mathrm{ng} / \mathrm{mL}$ has shown a significant reduction in PTH values. ${ }^{43}$ It is probable that the type of vitamin D used plays a key role. In recent tests, some which include CKD patients, and a systemic revision that included ten studies, it was observed that when comparing ergocalciferol with cholecalciferol the latter achieves serum levels of 25-hydroxyvitamin D in a more efficient and sustained way. This could be the result of a greater affinity of vitamin D3 for hepatic hydroxylase and vitamin D binding protein. ${ }^{44,45}$ In long-term studies it has also been observed that vitamin D3 achieves more sustained levels of 25-hydroxyvitamin D. ${ }^{46}$ These results are also confirmed when comparing vitamin D2 with D3 administered in low doses in a population of women in South Asia and European white women in the winter months, achieving vitamin D3 greater absolute increases in total serum vitamin D levels than the vitamin D2. ${ }^{47}$ The weekly dose of vitamin D, and its administration interval also intervene in the therapeutic result. The administration of vitamin D in doses of 1000 to $2000 \mathrm{IU}$ once or twice a week for a month fails to raise its serum levels satisfactorily, but if the dose is increased to a value between 3000 to $5000 \mathrm{IU}$ if it is effective. The reduction of the interval of vitamin D administration from 1000 to 2000 IU once or twice a week to 3,4,5,6 and 7 times a week has shown that the objective of serum levels of 25-hydroxyvitamin D was only obtained in the last group. ${ }^{48}$ Another more recent study in which diabetic CKD patients with stage 1 to 4 took part, compared the impact of the daily dose of $2000 \mathrm{IU} /$ day of cholecalciferol with $40.000 \mathrm{IU}$ administered monthly through 6 months of treatment. The serum concentrations of 25-hydroxyvitamin $\mathrm{D}$ at 3 and 6 months increased significantly in both groups, although in the group that took a daily dose there was a higher increase at 3 months. ${ }^{49}$ Regarding the interval in which the 25 -hydroxyvitamin $D$ values should be measured once it repositions could be every 3 to 4 months, based on its cost, long median life and security profile. ${ }^{29}$ To maintain serum 25 -hydroxyvitamin D levels above $30 \mathrm{ng} / \mathrm{mL}$ is the optimal value for CKD patients, in order to achieve the desired therapeutic effects. In our study we observed that the oral administration of vitamin $D$ elevates serum levels to normal values in a high percentage of CKD patients with stage 3 to 4 , thanks to the dose adjustment system to 4 months intervals, aiming to avoid the inappropriate accumulation, which reflects in the low percentage of patients who develop hypercalcemia. The dose of vitamin D used in most of them was $2000 \mathrm{IU} /$ day, and most of the patients who required dose of $4000 \mathrm{IU} /$ day were kidney transplant patients, which highlights the importance of immunosuppressors in altering its metabolism. ${ }^{6}$ In the group of patients refractory to the therapy, GFR values were the lowest, mainly corresponding to CKD stage 4, his renal deterioration was more accelerated, and in them the conversion to calcitriol achieved lower values of PTH and high of serum calcium and phosphorus, suggesting that a lower kidney mass equals lower conversion of 25-hydroxyvitamin D to calcitriol. Also, the activity of the 1 alpha hydroxylase could have been affected by higher serum levels of FGF 23, which were not evaluated. It is not clear why 17 patients (10\%) from the initial group of 170 patients were non responders to vitamin $\mathrm{D}$ therapy. This observation had already been described by other authors, and in that group of patients calcitriol or other active forms of vitamin D could be an alternative. ${ }^{50}$

In conclusion, our study confirms that cholecalciferol is an excellent therapeutic alternative to treat CKD patients with stage 3, and low levels of 25 hydroxyvitamin D. Its early administration can also avoid the onset of secondary hyperparathyroidism and correct it in those who already have it as long as the resulting normal serum values are observed, adjusting its 
dose. This is in accordance with the recent recommendations of the National Kidney Foundation, where they conclude that patients with CKD should be treated with native vitamin $\mathrm{D}$ (nutritional), before initiating therapy with active $\mathrm{D}$ (calcitriol) ${ }^{51}$ In the group of patients with GFR lower than $30 \mathrm{~mL} / \mathrm{min} / 1.73 \mathrm{~m}^{2}$ (stage 4 of CKD) and with secondary hyperparathyroidism, the use of active form of vitamin D (calcitriol, paricalcitol) could be required as the first therapeutic alternative.

\section{Limitations}

Vitamin D measured by electrochemiluminescence, and not mass spectroscopy, not initially incorporate patients with stage $4 \mathrm{CKD}$, and not incorporate other variables that reflect variations in bone and mineral metabolism.

\section{Ethical Approval}

All procedures performed in studies involving human participants were in accordance with the ethical standards of the institutional and/or national research committee and with the 1964 Helsinki declaration and its later amendments or comparable ethical standards.

\section{Informed Consent}

Neither consent form nor authorization from the patients was required since the therapy supplied did not constitute an experimental test and is recommended by international guidelines.

\section{Disclosure}

All the authors declare that they have no conflict of interest.

\section{References}

1. Dusso AS, Brown AJ, Slatopolsky E. Vitamin D. Am J Physiol Renal Physiol. 2005;289:F8-F28. doi:10.1152/ajprenal.00336.2004

2. Jones G. Extrarenal vitamin D activation and interactions between vitamin D2, vitamin D3, and vitamin D analogs. Annu Rev Nutr. 2013;33:10.1-10.22. doi:10.1146/annurev-nutr-071812-161203

3. Michigami T. Update on recent progress in vitamin D research. Vitamin D metabolism and its regulation. Clin Calcium. 2017;27:1517-1523. doi:10.CliCa171115171523

4. Wheeler DC, Winkelmayer WC. KDIGO 2017 clinical practice guideline update for the diagnosis, evaluation, prevention, and treatment of chronic kidney disease-mineral and bone disorder (CKD-MBD). Kidney Int Suppl. 2017;7:1-59. doi:10.1016/j.kisu.2017.04.001

5. Restrepo VCA, Aguirre AJV. Vitamin D $(25(\mathrm{OH}) \mathrm{D})$ in patients with chronic kidney disease stages 2-5. Colomb Med (Cali). 2016;47: 160-166. doi:10.25100/cm.v47i3.2148

6. Restrepo VCA, Aguirre AJV, Caceres ED. Determination of vitamin $\mathrm{D}(25(\mathrm{OH}) \mathrm{D})$ levels in renal transplant patients and their importance in accordance with the glomerular filtration rate. Rev Colomb Reumatol. 2018;25:161-168.
7. Gluba-Brzozka A, Franczyk B, Cialkowska-Rysz C, Olszewski R, Rysz J. Impact of vitamin D on the cardiovascular system in advance chronic kidney disease (CKD) and dialysis patients. Nutrients. 2018;10:6: 709. doi:10.3390/nu10060709

8. Zhang Y, Darssan D, Pascoe EM, Johnson DW, Pi H, Dong J. Vitamin D status and mortality risk among patients on dialysis: a systematic review and meta-analysis of observational studies. Nephrol Dial Transplant. 2018;33:1742-1751. doi:10.1093/ndt/gfy016

9. Liu M, Wang J, He Y. Serum 25-Hydroxyvitamin D were associated with higher risk of both albuminuria and impaired GFR incidence: a cohort study based on CLHLS study. BMC Nephrol. 2019;20:20. doi:10.1186/s12882-019-1202-8

10. Molina P, Gorriz JL, Molina MD, et al. What is the optimal level of vitamin $\mathrm{D}$ in non-dialysis chronic kidney disease population? World $J$ Nephrol. 2016;5:471-481. doi:10.5527/wjn.v5.i5.471

11. Eknoyan G, Levin A, Levin NW. K/DOQI clinical practice guidelines for bone metabolism and disease in chronic kidney disease. $\mathrm{Am}$ J Kidney Dis. 2003;42(suppl 3):S1-S202. doi:10.1016/S02726386(03)00905-3

12. KDIGO. Clinical practice for the diagnosis, evaluation, prevention, and treatment of chronic kidney disease-mineral and bone disorders (CKD-MBD). Kidney Int. 2009;76(suppl 113):S1-S130.

13. Alola JF. Clinical review: the 2011 report on dietary reference intake for vitamin D: where do we go from here? J Clin Endocrinol Metab. 2011;96:2987-2996. doi:10.1210/jc.2011-0090

14. Vieth R. Vitamin D supplementation, 25-hydroxyvitamin D concentrations, and safety. Am J Clin Nutr. 1999;69:842-856. doi:10.1093/ajen/ 69.5 .842

15. Lee JP, Tansey M, Jetton JG, Krasowski MD. Vitamina D toxicity: a 16 year retrospective study at an academic medical center. Lab Med. 2018;21:123-129. doi:10.1093/labmed/lmx077

16. Etayo HE, Restrepo CA. Acute tubular necrosis due to hypercalcemia secondary to vitamin D toxicity. Acta Med Colomb. 2010;35:99-102.

17. Garcia CA, Holguin MC, Caceres D, Restrepo CA. Importance of hyperphosphatemia in chronic kidney disease, how to avoid it and treat it by nutritional measures. Rev Colomb Nefrol. 2017;4:24-41.

18. Nordal KP, Dahl E. Low dose calcitriol versus placebo in patients with predialysis chronic renal failure. J Clin Endocrinol Metab. 1988;67:929-936. doi:10.1210/jcem-67-5-929

19. Toussaint ND, Damasiewicz MJ. Do the benefits of using calcitriol and other vitamin D receptor activators in patients with chronic kidney disease outweigh the arms? Nephrology (Carlton). 2017;22 (Suppl 2):51-56. doi:10.1111/nep.13026

20. Levey AS, Coresh J, Greene T, et al. Using standardized serum creatinine values in the modification of diet in renal disease study equation for estimating glomerular filtration rate. Ann Intern Med. 2006;145:247-254. doi:10.7326/0003-4819-145-4-200608150-00004

21. Dawson-Hughes B, Heaney RP, Holick MF, Lips P, Meunier PJ, Vieth R. Estimates of optimal vitamin D status. Osteoporos Int. 2005;16:713-716. doi:10.1007/s00198-005-1867-7

22. Dawson-Hughes B, Mithal A, Bonjour JP, et al. IOF position statement: vitamin D recommendations for older adults. Osteoporos Int. 2010;21:1151-1154. doi:10.1007/s00198-010-1285-3

23. American geriatrics society workgroup on vitamin D supplementation for older adults. Recommendations abstracted from the American Geriatrics Society Consensus Statement on vitamin D for prevention of falls and their consequences. $J$ Am Geriatr Soc. 2014;62:147-152. doi:10.1111/jgs.12631

24. Lips P. Vitamin D status and nutrition in Europe and Asia. $J$ Steroid Biochem Mol Biol. 2007;103:620-625. doi:10.1016/j.jsbmb.2006.12.076

25. Fuleihan GE-H. Vitamin D deficiency in the Middle East and its health consequences for children and Adults. Clinic Rev Bone Miner Metab. 2009;7:77-93. doi:10.1007/s12018-009-9027-9

26. Mithal A, Wahl DA, Bonjour JP, et al. Global vitamin D status and determinants of hypovitaminosis D. Osteoporos Int. 2009;20: 1807-1820. doi:10.1007/s00198-009-0954-6 
27. Holick MF, Binkley NC, Bischoff-Ferrari HA, et al.; Endocrine Society. Evaluation, treatment, and prevention of vitamin D deficiency: an endocrine society clinical practice guideline. J Clin Endocrinol Metab. 2011;96:1911-1930. doi:10.1210/jc.20110385

28. Chapuy MC, Preziosi P, Maamer M, et al. Prevalence of vitamin $\mathrm{D}$ insufficiency in an adult normal population. Osteoporos Int. 1997;7:439-443. doi:10.1007/s001980050030

29. Vieth R, Ladak Y, Walfish PG. Age-related changes in the 25-hydroxyvitamin $\mathrm{D}$ versus parathyroid hormone relationship suggest a different reason why older adults require more vitamin D. J Clin Endocrinol Metab. 2003;88:185-191. doi:10.1210/jc.2002021064

30. Dawson-Hughes B, Harris SS, Dallal GE. Plasma calcidiol, season, and serum parathyroid hormone concentrations in healthy elderly men and women. Am J Clin Nutr. 1997;65:67-71. doi:10.1093/ajen/ 65.1.67

31. Ross AC, Manson JE, Abrams SA, et al. The 2011 report on dietary reference intakes for calcium and vitamin $\mathrm{D}$ from the institute of medicine: what clinicians need to know. J Clin Endocrinol Metab. 2011;96:53-58. doi:10.1210/jc.2010-2704

32. Priemel M, von Domarus C, Klatte TO, et al. Bone mineralization defects and vitamin D deficiency: histomorphometric analysis of iliac crest bone biopsies and circulating 25-hydroxyvitamin D in 675 patients. J Bone Miner Res. 2010;25:305-312. doi:10.1359/jbmr. 090728

33. Shroff R, Wan M, Nagler EV, et al. Clinical practice recommendations for native vitamin $\mathrm{D}$ therapy in children with chronic kidney disease stages $2-5$ and on dialysis. European society for paediatric nephrology chronic kidney disease mineral and bone disorders and dialysis working groups. Nephrol Dial Transplant. 2017;32: 1098-1113. doi:10.1093/ndt/gfx065

34. Shroff R, Wan M, Gullett A, et al. Ergocalciferol supplementation in children with CKD delays the onset of secondary hyperparathyroidism: a randomized trial. Clin J Am Soc Nephrol. 2012;7:216-223. doi: $10.2215 / C J N .04760511$

35. Krause R, Roth HJ, Kaase H, Stange R, Holick MF. Vitamin D status in chronic kidney disease - UVB irradiation is superior to oral supplementation. Anticancer Res. 2016;36:1397-1401.

36. KDOQI WG. K/DOQI clinical practice guidelines for nutrition in children with CKD. Am J Kidney Dis. 2009;53:S11-S104.

37. Fried C, Zitt E. Vitamin D prohormone in the treatment of secondary hyperparathyroidism in patients with chronic kidney disease. Int J Nephrol Renovasc Dis. 2017;10:109-122. doi:10.2147/IJNRD. S97637

38. Alvarez JA, Law J, Coakley KE, et al. High-dose cholecalciferol reduces parathyroid hormone in patients with early chronic kidney disease: a pilot, randomized, double-blind, placebo-controlled trial. Am J Clin Nutr. 2012;96:672-679. doi:10.3945/ajen.112.040642

39. Westerberg P-A, Sterner G, Ljunggren O, et al. High doses of cholecalciferol alleviate the progression of hyperparathyroidism in patients with CKD stages 3-4: results of a 12-week double-blind, randomized, controlled study. Nephrol Dial Transplant. 2018;33:466-471. doi:10.1093/ $\mathrm{ndt} / \mathrm{gfx} 059$
40. Yadav AK, Kumar V, Kumar V, Banerjee D, Gupta KL, Jha V. The effect of vitamin D supplementation on bone metabolic markers in chronic kidney disease. J Bone Miner Res. 2018;33:404-409. doi:10.1002/jbmr.v33.3

41. Al-Aly Z, Qazi RA, Gonzalez EA, Zeringue A, Martin KJ. Changes in serum 25-hydroxyvitamin D and plasma intact PTH levels following treatment with ergocalciferol in patients with CKD. Am J Kidney Dis. 2007;50:59-68. doi:10.1053/j.ajkd.2007.04.010

42. Zisman AL, Hristova M, Ho LT, Sprague SM. Impact of ergocalciferol treatment of vitamin D deficiency on serum parathyroid hormone concentrations in chronic kidney disease. Am $J$ Nephrol. 2007;27:36-43. doi:10.1159/000098561

43. Thimachai P, Supasyndh O, Chaiprasert A, Satirapoj B. Efficacy of high vs conventional ergocalciferol dose for increasing 25hydroxyvitamin D and suppressing parathyroid hormone levels in stage III-IV CKD with vitamin D deficiency/insufficiency: a randomized controlled trial. J Med Assoc Thai. 2015;98:643-648.

44. Tripkovic L, Lambert H, Hart K, et al. Comparison of vitamin D2 and vitamin D3 supplementation in raising serum 25-hydroxyvitamin D status: a systemic review and meta-analysis. Am J Clin Nutr. 2012;95:1357-1364. doi:10.3945/ajcn.111.031070

45. Wetmore JB, Kimber C, Mahnken JD, Stubbs JR. Cholecalciferol v. ergocalciferol for 25-hydroxyvitamin D $(25(\mathrm{OH}) \mathrm{D})$ repletion in chronic kidney disease: a randomised clinical trial. $\mathrm{Br} J$ Nutr. 2016;116:2074-2081. doi:10.1017/S000711451600427X

46. Tripkovic L, Wilson LR, Hart K, et al. Daily supplementation with 15 ug vitamin D2 compared with vitamin D3 to increase wintertime 25-hydroxyvitamin D status in healthy South Asian and white European women: a 12 wk randomized, placebo-controlled food-fortification trial. Am J Clin Nutr. 2017;106:481-490. doi:10. 3945/ajen.116.138693

47. Oliveri B, Mastaglia SR, Brito GM, et al. Vitamin D3 seems more appropiate than D2 to sustain adequate levels of 25OHD: a pharmacokinetic approach. Eur J Clin Nutr. 2015;69:697-702. doi:10.1038/ejen.2015.16

48. Chao YS, Brunel L, Faris P, Veugelers PJ. The importance of dose, frequency and duration of vitamin D supplementation for plasma 25-hydroxyvitamin D. Nutrients. 2013;5:4067-4078. doi:10.3390/ nu5104067

49. Mager D, Jackson ST, Hoffmann M, Jindal K, Senior PA. Vitamin D3 supplementation, bone health and quality of life in adults with diabetes and chronic kidney disease: results of an open label randomized clinical trial. Clin Nutr. 2017;36:686-696. doi:10.1016/j.clnu.2016. 05.012

50. Bover J, Egido J, Fernandez-Giraldez E, et al. Vitamin D, vitamin $\mathrm{D}$ receptor and the importance of its activation in patients with chronic kidney disease. Nefrologia. 2015;35:28-41. doi:10.3265/ Nefrologia.pre2014.Sep.11796

51. Melamed ML, Chonchol M, Gutierre OM, et al. The role of vitamin $\mathrm{D}$ in CKD stages 3 to 4: report of a scientific workshop sponsored by the national kidney foundation. Am J Kidney Dis. 2018;72:834-845. doi:10.1053/j.ajkd.2018.06.031
The International Journal of Nephrology and Renovascular Disease is an international, peer-reviewed open-access journal focusing on the pathophysiology of the kidney and vascular supply. Epidemiology, screening, diagnosis, and treatment interventions are covered as well as basic science, biochemical and immunological studies. The manuscript management system is completely online and includes a very quick and fair peer-review system, which is all easy to use. Visit http://www.dovepress.com/testimonials.php to read real quotes from published authors. 